OECDpublishing

\title{
ENTREPRENEURIAL ACTIVITIES IN EUROPE
}

\author{
EXPANDING NETWORKS
}

OECD EMPLOYMENT POLICY PAPER

March 2015 No. 7 


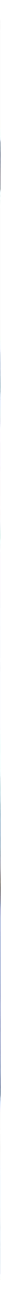

\section{Policy Brief on Expanding Networks for Inclusive Entrepreneurship}

Entrepreneurial Activities in Europe
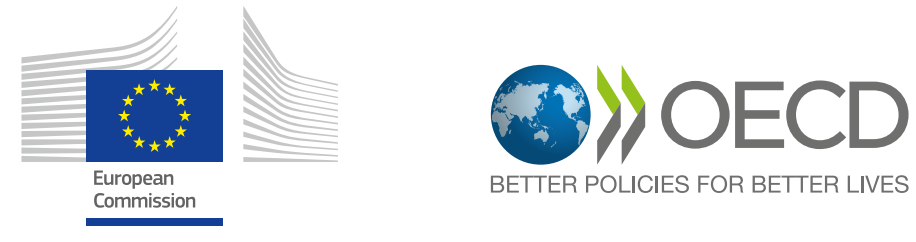
This paper is published under the responsibility of the Secretary-General of the OECD. The opinions expressed and the arguments employed herein do not necessarily reflect the official views of OECD member countries or those of the European Union.

This document and any map included herein are without prejudice to the status of or sovereignty over any territory, to the delimitation of international frontiers and boundaries and to the name of any territory, city or area.

Authorised for publication by Stefan KAPFERER, Director, Centre for Entrepreneurship, SMEs, Tourism and Local Economic Development.

1. Note by Turkey:

The information in this document with reference to "Cyprus" relates to the southern part of the Island. There is no single authority representing both Turkish and Greek Cypriot people on the Island. Turkey recognises the Turkish Republic of Northern Cyprus (TRNC). Until a lasting and equitable solution is found within the context of the United Nations, Turkey shall preserve its position concerning the "Cyprus issue".

2. Note by all the European Union Member States of the OECD and the European Commission:

The Republic of Cyprus is recognised by all members of the United Nations with the exception of Turkey. The information in this document relates to the area under the effective control of the Government of the Republic of Cyprus.

\section{Acknowledgements}

This paper was drafted by David Halabisky under the supervision of Jonathan Potter, both of the Local Economic and Employment Development (LEED) Division of the Organisation for Economic Co-operation and Development (OECD), with expert input from Sarah Drakopoulou Dodd of Middlesex University and ALBA Graduate Business School at The American College of Greece and Janroj Keles of Middlesex University. Additional input was provided by Sergio Destefanis of Università degli Studi di Salerno. This paper is part of a series of policy briefs on inclusive entrepreneurship produced by the OECD Local Economic and Employment Development Programme and the European Commission Directorate General for Employment, Social Affairs and Inclusion. This work is led by Jonathan Potter and David Halabisky of the OECD.

The links in this publication were correct at the time the manuscript was completed.

(c) Cover photo: Corbis

For any use or reproduction of photos which are not under European Union copyright, permission must be sought directly from the copyright holder(s).

\section{Europe Direct is a service to help you find answers to your questions about the European Union.}

\section{Freephone number $\left(^{*}\right)$ : 0080067891011}

$\left({ }^{*}\right)$ The information given is free, as are most calls

(though some operators, phone boxes or hotels may charge you).

More information on the European Union is available on the internet (http://europa.eu).

More information on the OECD is available on the internet (http://www.oecd.org). Luxembourg: Publications Office of the European Union, 2015

European Commission

ISBN 978-92-79-43387-0

Reproduction is authorised provided the source is acknowledged. 


\section{Policy Brief on Expanding Networks for Inclusive Entrepreneurship}

Entrepreneurial Activities in Europe 


\section{- CONTENTS}

KEY MESSAGES

WHAT ARE ENTREPRENEURIAL NETWORKS?. 3

WHAT IS THEIR SIGNIFICANCE FOR INCLUSIVE ENTREPRENEURSHIP? 5

HOW DO ENTREPRENEURIAL NETWORKS VARY ACROSS COUNTRIES AND REGIONS? 7

WHAT IS HINDERING THE ENTREPRENEURIAL NETWORKING OF DISADVANTAGED AND UNDER-REPRESENTED GROUPS? 8

HOW CAN POLICY SUPPORT NETWORK DEVELOPMENT?. 9

1. Building networks within the target group and linking them to the business community. 9

2. Integrating network creation with delivery of business development support 10

3. Broadening the scope of networks...

THE POTENTIAL OF ONLINE NETWORKS 14

CONCLUSIONS 15

SUGGESTED FURTHER READING 16

BIBLIOGRAPHY 16 
- Entrepreneurial networks are groups of interconnected entrepreneurs, business service providers and various other relevant people who entrepreneurs can access for information and ideas for the operation of their businesses in reciprocal relationships. These networks can help entrepreneurs access financing, find business partners, suppliers, employees and customers, and get ideas for new products, processes, organisational methods and business models. They can also influence an individual's perception of the desirability and feasibility of entrepreneurship.

- People from social groups that are under-represented or disadvantaged in entrepreneurship (e.g. women, youth, seniors, the unemployed, ethnic minority and migrant groups, people with disabilities) tend to have a greater need for entrepreneurial networks than mainstream entrepreneurs to help overcome shortcomings in their entrepreneurship skills and/or own financial and other resources. They also tend to have weaker entrepreneurial networks because they typically have had fewer opportunities to build professional relationships in educational, workplace and social contexts.

- Network building for entrepreneurs from under-represented and disadvantaged groups is therefore an important activity for public policy. The most common approach for public policy is to bring entrepreneurs and business services professionals with a common background together to build connections among themselves. Given their common backgrounds, the participants easily identify with each other and trust builds quickly. In addition to building these connections, public policy needs to pay attention to building bridges to entrepreneurs, business service providers and other stakeholders from other communities.

- Public policy can also create networks of entrepreneurs around other policy interventions such as training or other business development services. This has the advantages for programme delivery of generating economies of scale and ensuring that under-represented target groups are reached as well as having added benefits from the creation of networks among the participants. However, this approach excludes entrepreneurs who are not participating in the policy intervention. Moreover, these networks are not always sustainable when the binding factor is receipt of the training or business service.

- Public policy can also support the creation of international entrepreneurship networks through the joining up of national networks. These networks provide entrepreneurs with access to a wider pool of resources and ideas, and can be particularly useful for expanding into international markets.

- Online networks hold potential for public policy. They eliminate physical distances between entrepreneurs and offer some of the key characteristics of traditional networks including connections with other entrepreneurs that are built on trust and reciprocal relationships. The effectiveness of online networks is unknown but they offer a potentially important opportunity for policy because of their low-cost structures. However, policy makers must recognise that online networking initiatives likely need to be complemented with face-to-face interactions.

- One of the most important success factors for policy intervention is that network members have ownership of the supported networks. This can be achieved through the use of existing community structures and the involvement of network participants in the management of the network.

\section{WHAT ARE ENTREPRENEURIAL NETWORKS?}

Networks are groups of actors with a relationship or tie that connects them (Hoang and Antoncic, 2003; Nelson, 1988). The relevant networks for an entrepreneur include other entrepreneurs and people working in customer and supplier companies, business services providers, finance professionals and so on. The information and ideas flowing in these networks influence a person's attitudes to business start-up and can be a key resource for starting, growing and sustaining a business.

Social interactions are at the centre of entrepreneurial networks (Kim and Aldrich, 2005). For the entrepreneur or potential entrepreneur, these interactions can exist in several environments (Figure 1), including (Light and Bonacich, 1988; Portes, 1998; Glover et al., 2000; Flandreau, 2003; Morawska, 2004; Portes and Sensenbrenner, 1993; Waldinger et al., 1990):
- Workplace networks, which are composed of work colleagues, business partners and co-starters and business mentors;

- Market networks, which are composed of business collaborators, competitors, suppliers and customers;

- International networks, which are composed of business collaborators, competitors, suppliers and customers from another country and in another country;

- Professional networks, which are composed of business professionals (e.g. lawyers, accountants), financers (e.g. banks, investors) and other sources of information and support (e.g. researchers, business advisory services); and

- Identity-based networks, based on ethnic affiliation, cultural and linguistic commonalities, age and gender.
- Private networks, which are composed of spouses, parents, other family and friends; 
Figure 1. The entrepreneur's network

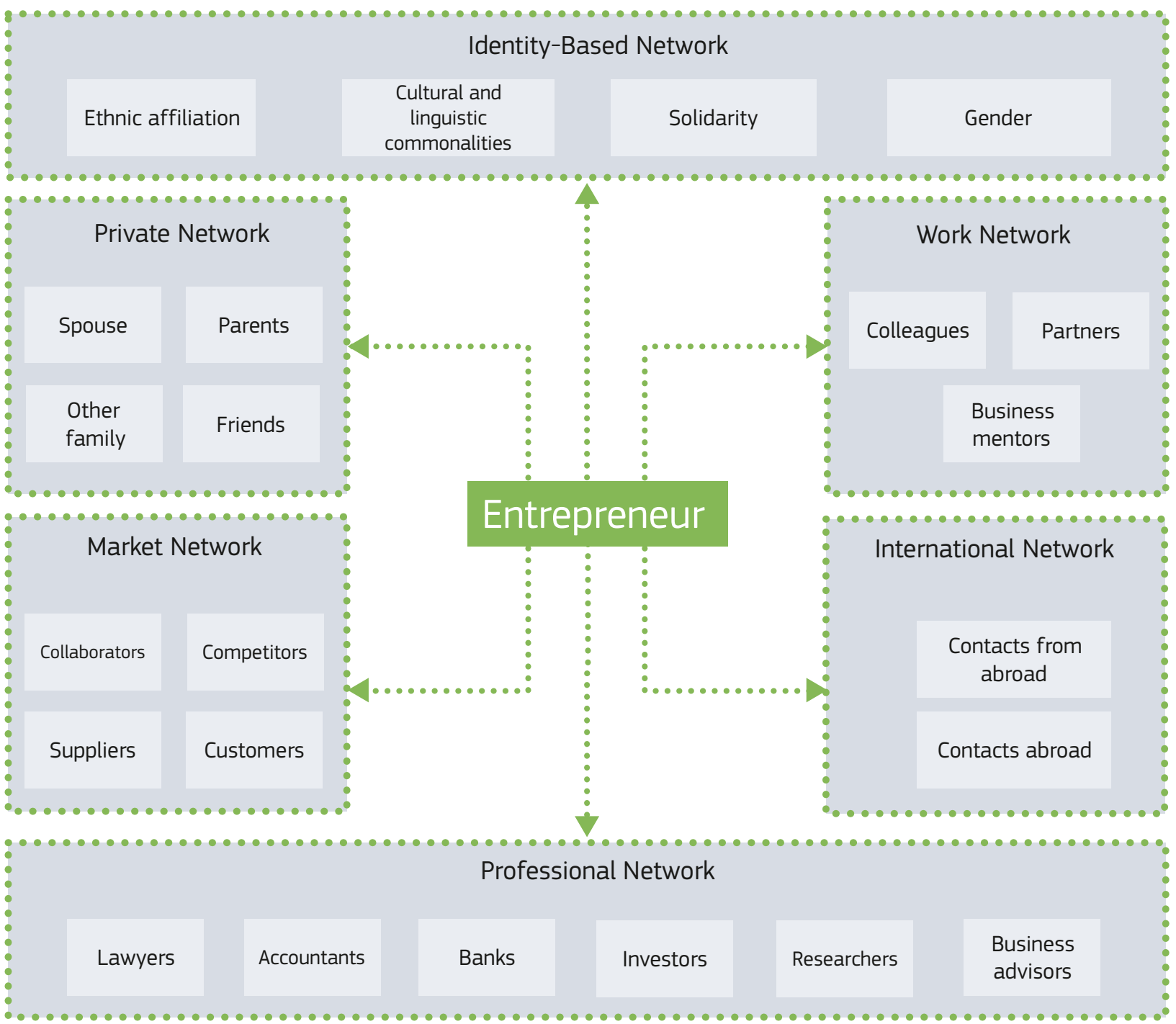

Source: Adapted from Schott and Cheraghi (2012).

It is difficult to clearly distinguish between personal and business networks for an entrepreneur. Often there is substantial overlap between these two types of networks and separating them is rather artificial. Instead, it makes sense to consider the overall social network of the entrepreneur, and examine the nature of each tie within it. An important characteristic of networks is the type of relationship between the actors in the network. This can be considered in terms of whether the networks are constructed around strong tie or weak tie relationships, or whether they are formal or informal.

Strong tie relationships can be seen as links with actors that entrepreneurs interact with at least twice per week and who are considered to be "close" to the entrepreneur (Granovetter, 1973). Most entrepreneurs tend to have quite small strong tie networks (Martinez and Aldrich, 2011), but these actors are willing to do a great deal for each other. Their greater knowledge of one another's situation enhances the "fit" and relevance of the information, support, services and resources exchanged. Held together by bonds of loyalty, trust and affection, strong ties are typically very important to entrepreneurs who are in the process of setting up a business. One of the drawbacks of a strong tie network is that the actors can be rather homogenous since people have a strong social tendency to group with those who are very much like them. Thus, strong tie networks can lack diversity in their reach, resources and (shared) perceptions.

In contrast, entrepreneurs use weak tie contacts less frequently. Interaction with these contacts occurs less than twice per week, but more than once per year. Entrepreneurs typically consider these contacts to be acquaintances (rather than friends), and this lower level of interaction results in lower expected benefits from this relationship. Although weak tie contacts may lack the insight and commitment to have profound impacts, their greater number and wider diversity, provides an enhanced "reach" into parts of the socio-economic environment not directly accessible 
by the entrepreneur (Jack, 2005). However, it is important to note that ties have a tendency to strengthen over time and entrepreneurs often convert their weak ties into strong ties (Jack et al., 2008). Current evidence suggests that diverse and balanced networks involving both strong and weak ties are important for entrepreneurs so that they can have both information and ideas tailored to their own situations and awareness of other opportunities and perspectives (Jack, 2005).

The formality of networks is also important because it influences how relationships are initiated and managed. Informal ("soft") networks are comprised of family, friends and acquaintances developed by the individual entrepreneur's life course. Formal ("hard") networks are those mediated through established institutions and organisations, such as chambers of commerce, trade associations, local policy initiatives, and alumni associations. Formal networks can also include social groups, such as sport clubs, religious or political bodies.

While both informal and formal networks are likely to be important to the entrepreneur (Birley, 1985), formal structures, although often more likely to offer targeted professional support, frequently appear off-putting and bureaucratic to entrepreneurs. For example, entrepreneurs have a history of avoiding enterprise and business development agencies (Birley et al., 1991; Hanna and Walsh, 2002). Formal networks are also likely to be less "rich" than network connections that develop "naturally" (Hanna and Walsh, 2002).

\section{WHAT IS THEIR SIGNIFICANCE FOR INCLUSIVE ENTREPRENEURSHIP?}

Networks can have a profound impact on the development of individual entrepreneurial intentions and motivations and a major role in the ability of people to identify business opportunities, validate business ideas and access resources such as customers, business partners, suppliers and advisors.

Entrepreneurial networks are especially relevant for entrepreneurs who belong to social groups that are under-represented or disadvantaged in entrepreneurship (e.g. women, youth, seniors, the unemployed, ethnic minority and migrant groups, people with disabilities). These groups often attribute lower desirability and perceived feasibility to pursue entrepreneurial career paths (OECD/The European Commission, 2013,2014 ), which are strongly shaped by the norms of their own communities and, experienced through entrepreneurs' interactions with others (Anderson and Miller, 2002). In addition, they often have lower levels of entrepreneurship skills, more difficulty in navigating the institutional and regulatory environment and more difficulty in accessing finance (OECD/ The European Commission, 2013). Appropriate networks can help them fill the gaps by accessing relevant information and ideas.

To understand the importance of networks for entrepreneurs, it is helpful to consider their impact at different stages of business start-up and development (Table 1). Prior to business start-up, strong ties provide the main foundation for the new venture (Lechner and Dowling, 2003) since they help the entrepreneur to identify and respond to opportunities, and to identify and secure resources (Hite, 2005; Larson and Starr, 1993). In most instances, existing social networks are crucial for new entrepreneurs and are likely to include family, friends and business contacts from earlier employment (Larson and Starr, 1993; Pages and Garmise, 2003; Ram, 2001). 


\begin{tabular}{|c|c|c|}
\hline $\begin{array}{l}\text { Stage of business } \\
\text { creation }\end{array}$ & Impact of networks & Examples \\
\hline Acquiring motivation & $\begin{array}{l}\text { The nature and intensity of entrepreneurial moti- } \\
\text { vation is strongly shaped by the norms of the } \\
\text { local environment, experienced through entre- } \\
\text { preneurs' interactions with others. Perceived } \\
\text { desirability, and perceived feasibility, of entre- } \\
\text { preneurial career paths are both learned by } \\
\text { potential and nascent entrepreneurs, through } \\
\text { their social networks. }\end{array}$ & $\begin{array}{l}\text { Family influence strongly shapes entrepreneurial } \\
\text { motivations. So, too, does a selection of strong } \\
\text { local role models (e.g. teachers). Specific ethnic } \\
\text { and religious traditions can also be very impor- } \\
\text { tant network-driven motivators. }\end{array}$ \\
\hline $\begin{array}{l}\text { Opportunity } \\
\text { perception }\end{array}$ & $\begin{array}{l}\text { Personalised information forms the basis of most } \\
\text { successful new business ideas, which is a function } \\
\text { of ties developed through personal, educational } \\
\text { and professional experience. }\end{array}$ & $\begin{array}{l}\text { Ideas for new products emerge through mar- } \\
\text { ket discussions with strong tie contacts, } \\
\text { often customers. }\end{array}$ \\
\hline Idea validation & $\begin{array}{l}\text { Early testing of entrepreneurship ideas typically } \\
\text { takes the form of discussion with potentially } \\
\text { important network contacts that are already } \\
\text { known to the entrepreneur. }\end{array}$ & $\begin{array}{l}\text { Moving from idea to concept is often guided by } \\
\text { dialogue with a tight circle of strong ties. }\end{array}$ \\
\hline $\begin{array}{l}\text { Resource } \\
\text { identification }\end{array}$ & $\begin{array}{l}\text { Searching for resources (i.e. partners, suppli- } \\
\text { ers, potential customers, financing, ideas), and } \\
\text { matching them to the needs of the planned new } \\
\text { venture, happens through personal interactions } \\
\text { between the entrepreneur and their contacts, who } \\
\text { may also broker links to resource holders. }\end{array}$ & $\begin{array}{l}\text { Securing start-up resources is often feasible only } \\
\text { through trusted strong tie contacts, including } \\
\text { family, friends, and close business colleagues. }\end{array}$ \\
\hline $\begin{array}{l}\text { Negotiating to get } \\
\text { into business }\end{array}$ & $\begin{array}{l}\text { Securing resources, customers, employees, sup- } \\
\text { pliers and distributors requires potential entrepre- } \\
\text { neurs to build exchange relationships with other } \\
\text { individuals, and their organisations. }\end{array}$ & $\begin{array}{l}\text { Previous professional contacts can be an impor- } \\
\text { tant driver for new businesses. }\end{array}$ \\
\hline Business development & $\begin{array}{l}\text { Launching the venture requires that entrepre- } \\
\text { neurs move from planning with others, to acting } \\
\text { with them. Networks provide access to resources } \\
\text { that help entrepreneurs launch and grow their } \\
\text { businesses, including potential partners, suppliers, } \\
\text { customers and employees. Networks can also be } \\
\text { used as a source of advice, information and ideas. }\end{array}$ & $\begin{array}{l}\text { Business launch is dependent on a new idea, } \\
\text { while survival and growth are dependent on } \\
\text { resources and new alliances - which are all medi- } \\
\text { ated through networks. }\end{array}$ \\
\hline
\end{tabular}

Source: Adapted from Drakopoulou Dodd and Keles (2014).

After the business is established, the entrepreneur's network generally expands to include a wider pool of contacts, the majority of which are weak tie contacts. These new contacts typically bring diverse benefits to the entrepreneur (Jack et al., 2008), including contacts with competitors (Lechner and Dowling, 2003). Existing relationships often become multiplex and can no longer be easily defined as purely social, or economic, but combining multiple dimensions. This means that weak ties become stronger, and social ties have economic content added to them (Larson and Starr, 1993; Johannisson, 1996).

When firms are established and seeking to grow, entrepreneurs often transfer the management of many strong ties to managers within the business (Larson and Starr, 1993; Jack et al., 2008). This allows entrepreneurs to re-engage with their enlarged pool of contacts (i.e. business collaborators, competitors, suppliers and customers), to search for growth ideas, opportunities, and resources, and, subsequently, to enact them (Greve and Salaff, 2003; Jack et al., 2008; Lechner and Dowling, 2003). At this point of business development, it is important for entrepreneurs to move beyond identity-based strong ties to avoid being held back by an over-reliance on family and friends (Drakopoulou Dodd et al., 2014; Johannisson and Mønsted, 1997).

Entrepreneurial networks could make an important difference to decisions to start-up businesses and to subsequent business success by people from disadvantaged and underrepresented groups in entrepreneurship, but tend to be more limited, hence exaggerating the existing inequalities of opportunity in this area. 


\section{HOW DO ENTREPRENEURIAL NETWORKS VARY ACROSS COUNTRIES AND REGIONS?}

The structure and processes of entrepreneurial networks vary across regions and countries, sometimes quite dramatically. Figure 2 presents results of recent research for selected EU and
non-EU countries on mean numbers of network contacts, hours spent networking per week, and network density (i.e. proportion of network that are not family or friends).

Figure 2: Patterns of entrepreneurial networks

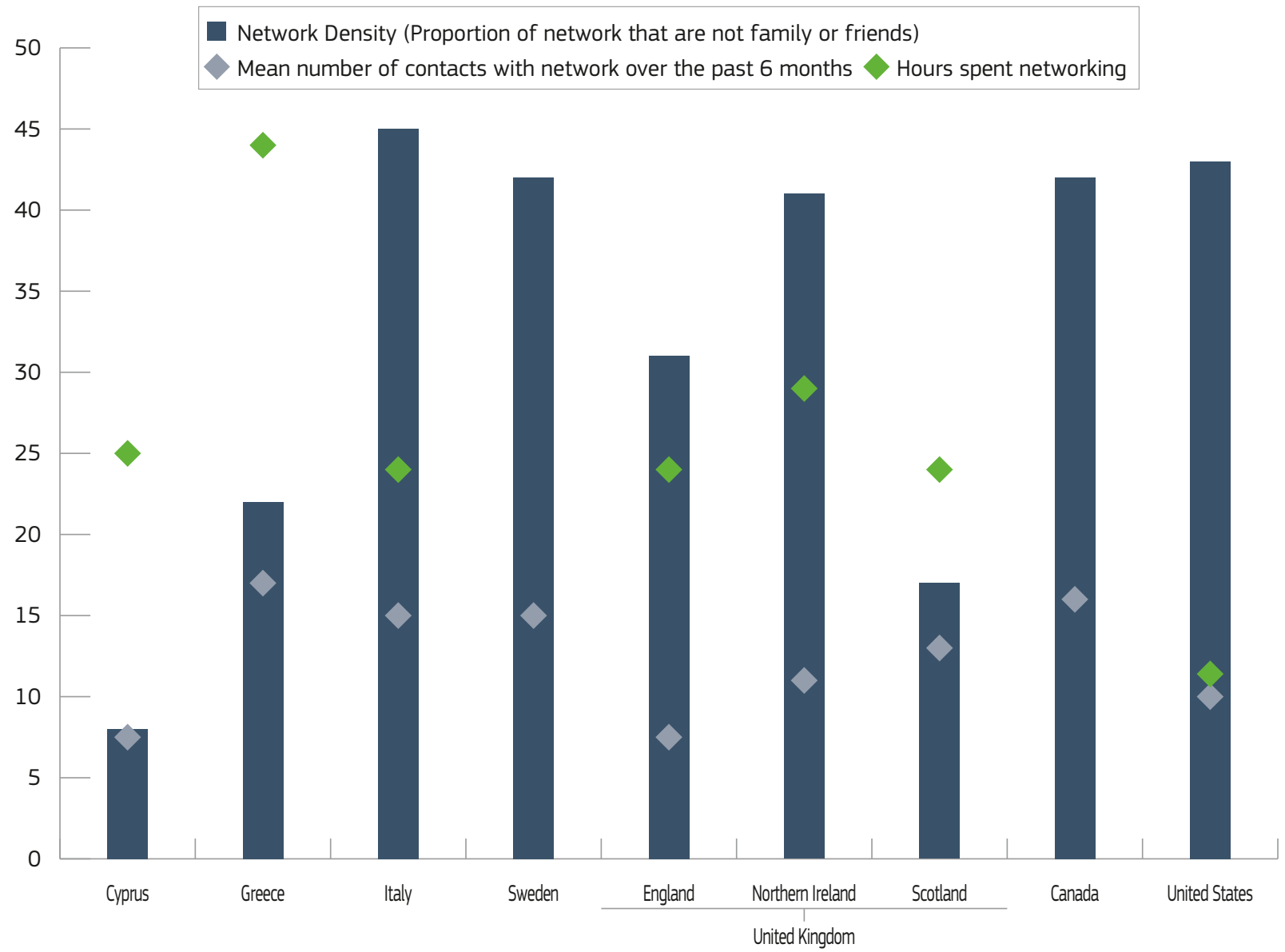

Source: Drakopoulou Dodd (2012).

Figure 2 reveals that the proportion of an individual's entrepreneurial network contacts that are not family and friends varies substantially across countries and regions. The networks of entrepreneurs in the United States, Canada, Italy and Sweden include more professional relationships than the other countries investigated. In addition, the amount of time spent networking varies significantly across countries. The numbers of contacts made with the network also varies, although not to the same extent as time spent on networking or proportion of networking with professional rather than social contacts.

The local economic environment is also an important influence on entrepreneurial networks. Some local economies exert a positive influence on entrepreneurial networks through the availability of opportunities for collective learning and knowledge creation. This is often driven by the presence of sectoral clusters and regional business communities (Camagni, 1991; Pages and Garmise, 2003), which play a role in supporting the development of trust-based informal social relationships, and exploiting intangible, un-traded interdependencies (Johannisson and Mønsted, 1997; Storper, 1995; De Propris, 2000; Drakopoulou Dodd, 2012). On the other hand, some local economies exert a negative influence because of economic stagnation and a culture of dependency on large firm and public sector employment (Venkataraman, 2004; Vanhaverbeke, 2001). Local contexts characterised by high unemployment and social exclusion have repeatedly been shown to enact forms of entrepreneurship confined to a very narrow range of lowcapital, low-skill, easily imitable service sectors (Mole et al., 2009), with high failure rates. Support to build the scale and scope of entrepreneurial networks for people living in these environments could be particularly important. 


\section{WHAT IS HINDERING THE ENTREPRENEURIAL NETWORKING OF DISADVANTAGED AND UNDER-REPRESENTED GROUPS?}

People from under-represented and disadvantaged groups in entrepreneurship typically face greater challenges in building entrepreneurial networks than people from the entrepreneurship mainstream. Critically, the pool of resources (e.g. knowledge, skills, perceptions of high-growth potential opportunities, finance) available through their family and friends, which are typically their most important network contacts (Drakopoulou Dodd et al., 2014; Schör, 2006), is commonly less rich because many of their family and friends face the similar disadvantages. There is therefore a need to substitute other sources of "social capital" for those not found within their strong-tie networks of family and friends. However, people from disadvantaged and under-represented groups in entrepreneurship tend to lack access points to expand their weak-tie networks because they are typically excluded from network-rich contexts (i.e. educational, cultural and workplace contexts).

\section{Social capital}

The concept of social capital became fashionable only relatively recently, but the term has been in use for almost a century while the ideas behind it go back further still. "Social capital" may first have appeared in a book published in 1916 in the United States that discussed how neighbours could work together to oversee schools. Author Lyda Hanifan (1916) referred to social capital as "those tangible substances [that] count for most in the daily lives of people: namely goodwill, fellowship, mutual sympathy, and social intercourse among a group of individuals and families who make up a social unit".

That gives some sense of what's meant by social capital, although today it would be hard to come up with a single definition that satisfied everyone. For the sake of simplicity, however, we can think of social capital as the links, shared values and understandings in society that enable individuals and groups to trust each other and so work together.

Source: Keeley, B. (2007), "OECD Insights: Human Capital - How what you know shapes your life”, Paris: OECD Publishing. DOI: 10.1787/9789264029095-en

There are also a number of more specific issues in entrepreneurial networking that affect particular social groups.

\section{Women}

There is long-standing evidence that female entrepreneurs tend to have entrepreneurial networks that are more limited in size and diversity than male entrepreneurs (Carter et al., 2001; Drakopoulou Dodd and Keles, 2014; Hampton et al., 2009; Storey 1994). Furthermore, women are less likely to be able to draw on relevant social capital from previous work experiences (Metcalfe, 1998; Kellard et al., 2002). Women's entrepreneurial networks appear more likely to include educators rather than business services providers or entrepreneurs (Ernst and Young, 2013). Moreover, women entrepreneurs appear more likely than men to develop informal, affective and strong-tie networks, whereas men tend to favour formal, calculative/instrumental, and weak-tie networks (Hampton et al., 2009).

A study in Northern Ireland that interviewed women entrepreneurs found that among the reasons why women are less likely to participate in entrepreneurial networks is a lack of self-confidence and anxiety about discrimination by others in the network (Hampton et al., 2009).

Women who have children face an additional challenge because child-bearing typically introduces breaks into career and workplace activities. These can disrupt work-based network relationships, which results in a need to exert more effort in maintaining and re-establishing networks around these periods.

\section{Youth}

Young people tend to lack business and work experience, and hence networks, by simple fact of their age. They also tend to lack assets relevant to entrepreneurship, including financial, human and social capital (EC-OECD, 2012). The latter means that they often struggle to build legitimacy among financers, suppliers, customers and others. In network relationships that function largely on the basis of reciprocity, a central challenge is that young people often have very little to offer to the network.

\section{Seniors}

Contrary to many other entrepreneurs from under-represented and disadvantaged groups, older people who are looking to set up a business often have a large amount of human, social and financial capital that was developed over a long career. With so much to bring to an entrepreneurial network, older entrepreneurs can use their knowledge and experience to leverage networks through mutually beneficial relationships. Moreover, this creates the possibility of older entrepreneurs acting as mentors both to their peers, as well as to younger age cohorts. Nonetheless, potential older entrepreneurs can face challenges related to developing networks, particularly if they have become disconnected from their workplace ties (through retirement or 
a period of unemployment). Older entrepreneurs can also face negative and unsupportive attitudes from their closest strong ties (i.e. family and friends) and others in the community (e.g. partners, suppliers and customers).

\section{Ethnic minorities and migrants}

Many ethnic minority and migrant communities have a strong entrepreneurial orientation, which provides many avenues to find entrepreneurial role models, other entrepreneurs and entrepreneurship-oriented community support structures (Wang and Altinay, 2012). Moreover, immigrant entrepreneurs often have opportunities to build international networks as a result of their mobility, which can allow them to easily access ideas and advice from different perspectives and prospects to exploit international markets.

At the same time, ethnic minority and migrant entrepreneurs may have difficulty building networks in a new context, given challenges related to language and difficulties adapting to a new institutional and regulatory environment (OECD/The European Commission, 2014). There are also specific challenges for policy makers who are seeking to support networks for ethnic minority and migrant entrepreneurs. First, an existing base of strong community network structures can lead to "over-crowding" in specific business sectors associated with diverse ethnic groups (e.g. small-scale retail or catering sectors). Second, many ethnic minority and migrant entrepreneurs operate in sectors that are characterised by long working hours. This creates a challenge for ensuring that the support is accessible. Third, ethnic minority and migrant groups generally have a mistrust of government and public initiatives (Vickers et al., 2009). A final challenge that policy makers need to be mindful of is the interplay between gender and religion. In some communities, women entrepreneurs may not be able to attend one-on-one meetings with men.

\section{Unemployed}

The long-term unemployed typically face multiple forms of deprivation, including difficulties accessing housing, education, health, work opportunities, and physical infrastructure. These factors are all challenges when setting up a business for the unemployed and make it difficult to build entrepreneurial networks. Another challenge is that unemployed people do not have access to a workplace, which is an important resource for developing professional relationships. This becomes more challenging as the length of unemployment increases because these ties weaken over time if the relationships are not maintained.

\section{- HOW CAN POLICY SUPPORT NETWORK DEVELOPMENT?}

There are three main types of public programmes that seek to build the entrepreneurial networks of people from underrepresented and disadvantaged groups in entrepreneurship: programmes specifically designed for building connections among entrepreneurs from the same target population and linking them to a broader business community; programmes designed to deliver advice, training and consultancy that seek to build networks alongside the main service; and programmes that focus on building international entrepreneurial networks. The goals, approaches and examples of typical interventions are set out below for each programme type.

\section{Building networks within the target group and linking them to the business community}

\section{Goal}

This type of action aims to expand the resource base of entrepreneurs from under-represented and disadvantaged groups by helping them connect with their local business communities including potential suppliers, business partners and customers. A secondary aim is to help start-up entrepreneurs from disadvantaged and under-represented groups to build credibility and trust for themselves and their new businesses, which is especially important for women, youth and the unemployed. Network-based trust can build self-confidence and allows the entrepreneurs to "punch above their weight" with the credibility that their contacts bring to them. A further significant function of the networks is to provide a set of relevant entrepreneurial role models, which can help increase perceptions of the desirability and feasibility of entrepreneurship among people in the targeted groups.

\section{Approach}

Public policy initiatives in this area typically aim to develop networks within specific population groups, e.g. networks of young entrepreneurs, networks of women entrepreneurs or networks of ethnic minority entrepreneurs. This results in networks among the entrepreneurs of that community, mixing new entrepreneurs in need of support with established entrepreneurs and business service providers from the same community. There are clear incentives for both novice and experienced entrepreneurs to participate. Novice entrepreneurs have an opportunity to meet both new and experienced entrepreneurs who can offer advice and encouragement. At the same time, experienced entrepreneurs can meet each other as well as "give back" to the community by supporting less experienced entrepreneurs.

In practice, entrepreneurial networks facilitate interactions between network members with regular face-to-face meetings, conferences, social events, workshops and opportunities for online interaction. Networks that are local often have monthly gatherings or workshops, while those that are 
regional, national or international have events less frequently. To manage this, policy makers should appoint an appropriate number of network managers, depending on the network's size and scope, with two core responsibilities. First, they must develop a communication channel with members. Often this is a website but many networks also maintain newsletters that are distributed via email. This requires that the network manager builds and maintains a membership database and mailing list, which may or may not be shared within the network membership. A second core responsibility of the network manager is to organise regular events to ensure that members remain engaged in the network.

An example of a network that organises events and manages their membership through a website is Be-Win in Italy (see Policy example 1). The network's website has a "members only" section which advertises upcoming events and conferences, and allows members to connect with each other using a search engine to identify network members in specific sectors or with specific competences.

Policy example 1: Be-Win - Business Entrepreneurship-Women in Network, Italy

Target group: Be-Win is a network for women entrepreneurs.

Intervention type: A network and information portal for women.

Description: The project was co-funded by the European Commission and co-ordinated by the Union of Chambers of Commerce in Tuscany. It involved the construction of a female entrepreneurial network built around a group of approximately 30 female "ambassadors" with experience in managerial and entrepreneurial fields. This core group of women entrepreneurs were identified through a public selection process or through the previous Women Ambassadors in Italy project. The network also has approximately 50 new female entrepreneurs, who joined the network by making an application through the network's website. The network uses its website to connect members, promote networking and training events, and to disseminate information. The annual public cost of the network is approximately EUR 172000, of which EUR 59000 was covered by the regions, EUR 70000 came from EU funds and the remainder came from private donors.

Results achieved: The project led to (a) the creation of an Italian Network of Women Entrepreneurship Mentors, inserted into the wider European network and (b) an Internet portal as a meeting place and a tool at the disposal of all those women in business who want to know each other better, develop potential synergies and co-operation with a view to the growth of their companies.

Lessons for other initiatives: The network built upon the previous Women Ambassadors in Italy project and benefits from international linkages in the form of the Enterprise Europe Network Italia and the European Network of Ambassadors. The portal has also demonstrated to be a useful resource that provided a tangible benefit for network members.

For more information, please refer to: http://www.be-win.it.

A key consideration for policy makers in developing targeted networks for entrepreneurs from under-represented and disadvantaged groups is outreach. Policy makers should try to leverage existing community partners and communication channels to promote the networks to the target groups. These channels are important because they have an established level of trust with the client group. This is particularly important for ethnic minority and immigrant entrepreneurs who, as noted earlier, are more likely to distrust public support schemes. For example, Cre'Action in Dunkirk, France built a network of young and experienced entrepreneurs from North Africa in France and North Africa by partnering with the Centre d'Éducation et de Formation Interculturel Rencontre, which had a long history of working with the North African community in Dunkirk.

Policy makers also need to ensure that network managers are trained in the special needs and challenges of the different target groups. This is particularly important for entrepreneurs with disabilities who face challenges that are not well-known or understood by those who do not have the same disability.

\section{Integrating network creation with delivery of business development support}

\section{Goal}

This approach to building entrepreneurial networks adds a networking element to the provision of basic business development services to entrepreneurs from selected under-represented and disadvantaged groups. Thus when a scheme is designed to provide training, coaching and mentoring, financial supports or similar services, actions are developed in parallel to specifically stimulate the creation of networks among the programme beneficiaries. This approach can help overcome the inherent challenge of outreach to potential beneficiaries, especially those 
who are in groups that traditionally have a distrust of public support (e.g. ethnic minority and immigrant groups).

\section{Approach}

These hybrid programmes typically combine training, advice or consultancy services to entrepreneurs and potential entrepreneurs from specific target groups with opportunities for group interactions with other programme participants and meetings with entrepreneurs and business service providers from outside the programmes. Policy examples 2 and 3 set out the cases of Unternehmer Ohne Grenzen in Germany and Mature Entrepreneur in Poland. Both are structured training schemes that built networks for cohorts of training participants.

\section{Policy example 2: Unternehmer Ohne Grenzen ("Entrepreneurs Without Borders"), Germany}

Target group: Unternehmer Ohne Grenzen is a network for ethnic minorities and immigrant entrepreneurs.

Intervention type: This is a training and networking scheme.

Description: The scheme was launched by entrepreneurs of different nationalities in 2000 as a platform for mutual exchange. Set-up as an association, the organisation works to strengthen the local economy in Hamburg. It promotes business startup, especially for people with a migrant background, and also promotes the participation of women in economic life. The programme offers both training and networking support to potential and new entrepreneurs who have a migrant background. Services are offered in Turkish, Russian, English, Spanish and French and are offered free-of-charge to participants. The networking support includes referring participants to mainstream business support agencies for resources and support and offering gateways to private sector entrepreneurs, investors and business service providers through the programme's trainers and consultants. The project has an annual budget of approximately EUR 280000.

Results achieved: The scheme supports 150 entrepreneurs each year with training and networking support.

Lessons for other initiatives: One of its main challenges is reaching potential clients. Migrant community media are used for advertising, including periodically appearing on German-Turkish television programmes.

For more information, please refer to: http://www.uog-ev.de.

\section{Policy example 3: Mature Entrepreneur, Poland}

Target group: Potential entrepreneurs over the age of 50.

Intervention type: Training and consultancy with built in networking opportunities.

Description: Poland's Mature Entrepreneur project, developed by the Gdansk Municipal Employment Office, aimed to provide guidance and financial support to individuals aged between the ages of 50 and 64 to help them remain attached to or re-enter the labour market through business creation in a context of low employment, high unemployment and little entrepreneurial activity among older workers (only $7 \%$ of all local start-ups are by workers aged 50 and above).

Participants were selected into the programme through a 5-minute oral presentation on their business idea to a panel of business experts in the Gdansk Municipal Employment Office. In 2009-10, 60 candidates were selected and were divided into 3 groups. Each participant took a 150-hour training programme and had access to experienced professional consultants. Upon completion of the course, participants could apply to receive financial assistance from the programme and 26 participants received this one-time subsidy and income supports for 6 months. The project was supported by the European Social Fund (ESF) from January 2009 to December 2010. The total budget was EUR 500000.

The project supported the expansion of networks for participants in two respects. First, the 3 groups of participants undertook a long training programme together and got to know each other very well. This provided each with a network of peers that could support and help them. Second, the interaction with professional coaches further increased their networks because each participant could access their knowledge and resources.

Results achieved: Mature Entrepreneur fostered the establishment of 33 new companies. All of the newly established companies are still active, with some growing so much that further full-time positions were created.

Lessons for other initiatives: The strength of the Mature Entrepreneur project is that it is based around a structured support training and advice programme that is delivered in stages. Those who move from one stage to the next can then be offered further adapted support, increasing their chances of success. Another important success factor is that the focus is strictly on entrepreneurship, whereas many other projects have a much broader labour market focus. 
This approach to building networks uses the business development support provision as the backbone of the network. Therefore, outreach is less of a concern for policy makers since the target members are already connected through another form of support. Instead, the network should be treated as the key "selling" feature of the integrated support provision. Moreover, policy makers will have access to experienced entrepreneurs, i.e. the trainers, consultants, coaches and mentors. This group will also be an integral part of the network because they will be needed to help connect the network to the wider business community by engaging and involving their contacts in network events.

Even though this approach to building entrepreneurial networks leverages an existing infrastructure (e.g. training course) to bring people together, policy makers should also consider developing a dedicated network platform to disseminate information and to serve as a direct link between network members. This could be a newsletter or website, for example. Websites offer the potential to grow networks beyond a single cohort of beneficiaries and also provides network members with an opportunity to continue interacting with the network after the business development support finishes.

One of the strengths of this approach is that it enables the creation of networks quickly and effectively, and can obtain additional networking benefits from general business services support at little marginal cost. Entrepreneurs that are already participating in a support scheme are also more likely to engage in the network because there is likely a high level of trust with other network members. At the same time, however, the coupling of networks and other business development services has a drawback - it may exclude those who are not seeking training, consultancy or other support.

\section{Broadening the scope of networks}

\section{Goal}

Many entrepreneurial network initiatives operate at the local or regional level and within specific target populations. This type of programme aims to broaden out the contacts made to a more diverse group of entrepreneurs and service providers, both nationally and internationally. This can be of interest to entrepreneurs who are seeking new ideas and perspectives as well as those seeking to expand their businesses into national and international markets and are trying to find appropriate business partners, suppliers and customers. This approach is particularly relevant for women and youth entrepreneurs.

\section{Approach}

One type of approach in this area is to create national or international network organisations for entrepreneurs from specific target populations by joining up existing national or regional network organisations. These networks often have annual conferences that allow for face-to-face meetings and workshops and use websites and newsletters to disseminate information. The umbrella network then operates in parallel and in addition to the previous national and regional networks. As discussed earlier, this approach requires a network manager to organise conferences and events, and to disseminate information to members. An example of joining existing regional networks into a national network is the Women Entrepreneurs Network created in the Czech Republic, which is composed of the Association of Women Entrepreneurs and Managers of the Czech Republic, Moravian Association of Women Entrepreneurs and Managers, South Bohemia Association of Women Entrepreneurs and Managers and Central Bohemia Association of Women Entrepreneurs and Managers.

Another type of approach is to seek to create crosscountry connections for disadvantaged and under-represented entrepreneurs and those concerned through the provision of appropriate business development support services, information or a vehicle for political representation at the EU-level. For example, Female Europeans of Medium and Small Enterprises is a network that spans 7 European countries and 15 organisations (see Policy example 4). 
Policy example 4: Female Europeans of Medium and Small Enterprises (FEM)

Target group: Female entrepreneurs.

Intervention type: FEM is a European umbrella organisation for national and regional associations of women in small and medium-sized enterprises.

Description: Established in 1990, FEM has 15 member organisations in 10 European countries and aims to improve the equal opportunities, social, cultural and social position of female entrepreneurs in small and medium-sized businesses. In addition to working to encourage entrepreneurship for women in the EU, FEM acts as a network where women can exchange knowledge and experiences with other women entrepreneurs. It also acts as a contact point for entrepreneurs belonging to member associations to access resources in other member associations. FEM uses social media and the internet to engage to members and to promote their activities.

In addition to being its own network, FEM is a member of the European Association for Craft, and Small and Medium-sized Enterprises (UEAPME). The UEAPME monitors EU policy and legislative processes and informs members on a matters related to crafts, trade and SMEs. The Association also represents and promotes member interests to EU institutions and supports members on technical and legal policy matters.

Results achieved: FEM has existed as a relevant international network of female entrepreneurs for 25 years.

Lessons for other initiatives: FEM has a clearly defined mandate that guides its activities. It also has a clear organisational structure, with a defined process of electing a president, vice presidents and a treasurer to ensure that network members drive the networks activities.

For more information, please refer to: http://www.fem-online.eu/.

The value of broadening networks to the national and international levels is that it expands an entrepreneur's weak ties so that they have better opportunities to exploit non-local markets, suppliers and technologies. Furthermore, since members come from similar backgrounds and may have affinity for one another there are some good opportunities for exchanges of valuable information or advice. However, strong tie connections between the individuals are generally likely to be limited. Joint networking events at national or international levels, for example, are normally held only infrequently. 
The internet has changed business relationships for entrepreneurs by enabling them to communicate rapidly, cheaply, and extensively. New "virtual communities" are emerging in which information and knowledge is shared electronically by individuals with common interests. Although not necessarily located close to one another in space, participants in these communities can share a degree of trust and reciprocity based on shared mutual interests and experiences (Larsen and Urry, 2008). Access to these virtual communities is through the use of information and communications technologies (ICT), including setting up and consulting web pages, email, social media and other communication tools (e.g. Skype, Facetime).

It is important that entrepreneurs and potential entrepreneurs from under-represented and disadvantaged social groups make use of the internet for the development of their entrepreneurial networks. It offers a way of communicating with a much larger and more diverse group of potential partners than would be possible without it. Online networks could be even more important for some inclusive entrepreneurship target groups. For example, physically disabled people often find that they can more easily use the internet for networking than participate in physical events, while the internet helps people from immigrant communities to have cheap, rapid and multiple linkages with business contacts in their home countries.

These trends suggest the need for two main lines of policy intervention with respect to inclusive entrepreneurship. First, public policy should promote online networks of entrepreneurs as a method of supporting inclusive entrepreneurship. This may be done by promoting stand-alone networking initiatives for specific target populations. An example is Biiugi, http://www.biiugi.eu, which is targeted at entrepreneurs over the age of 50 in Poland, Denmark and Germany in order to bring together ideas, knowledge and people for cross-national entrepreneurial co-operations. It includes online matching between novice and experienced entrepreneurs based on self-identified needs and profiles that are completed upon registration. It may also be done by complementing other types of networking initiatives, based for example on face-to-face contacts in seminars, mentoring and training activities, with additional virtual networking among participants and external contacts. This approach is taken in Be-Win in Italy (see Policy example 1) where members can search for other members with specific experiences or competences. In both cases, the policy initiative needs to create an appropriate online platform, direct members to the platform and animate core network activities to keep the network alive and thriving, for example by making regular interventions (such as Tweets) on social media and convening online webinars. Although generally cost effective, such initiatives are likely to fail to achieve impact if the effort required for animation is under-estimated.

Second, efforts are needed to increase the capacities and motivations of entrepreneurs and potential entrepreneurs from under-represented and disadvantaged communities to engage in online networking. Policy actions may facilitate access to adapted online networking tools and offer basic training and support in their use. The need for these interventions stems from the fact that - as opposed to use of the internet in general - some of the most powerful tools for professional networking on the internet (e.g. Facebook, Twitter, Linkedln) are mainly used by computer literate and young entrepreneurs. Many groups targeted by inclusive entrepreneurship policies, such as seniors, the unemployed and ethnic minorities, make substantially less use of these tools (Beckinsale et al., 2011). The issue this raises is that online networking services for entrepreneurs promoted by governments and development agencies are not equally accessible to all. Indeed, it has been claimed paradoxically that in an increasingly information-rich age, computer illiterate people are becoming increasingly "information-poor" (Greco and Floridi, 2004; Hongladarom, 2004; Norris, 2001). Capacity-building efforts should help to increase the proportions of under-represented and disadvantaged entrepreneurs participating in online networking. At the same time, however, virtual networking should not be the sole type of networking support initiative promoted by public policy for disadvantaged and under-represented groups in entrepreneurship. More traditional, face-to-face networking methods are also needed to reach people who are less prone to operate on the internet.

Finally, it should not be assumed that providing information on administration and regulations regarding starting and running businesses is sufficient for all groups. Some means of face-to-face contacts should also be offered. 
Entrepreneurs gain multiple benefits from their networking activities, including an expansion of their resource base, learning about business processes and opportunities, and generating reputation and legitimacy. However, entrepreneurs from under-represented and disadvantaged groups typically have more limited networks because they are more likely to rely on friends and family who typically face similar disadvantages. It is thus no surprise that policy makers, at local and national level, have long looked to network development as a mechanism for enhancing the entrepreneurial potential of the disadvantaged.

Several key factors for the success of such initiatives can be identified. First, network structures and processes should be designed to ensure a high degree of interaction between the entrepreneurs in the network and the wider business community. This will ensure that entrepreneurs from under-represented and disadvantaged groups have access to a greater pool of resources to help them overcome their business problems. In addition, building a strong bridge between the network and the wider business community will ensure that the network does not further isolate the group of disadvantaged entrepreneurs and reinforce their disadvantage.

Secondly, policy makers should set up clearly defined objectives for entrepreneurial networks. These objectives will shape the structure and processes of the network. For example, some of the policy actions provided in this policy brief illustrate how networks are combined with delivering entrepreneurship training and access to financing. This type of network will require a very different structure than one that aims to build international connections and facilitate exporting and business expansion. Having a clear purpose will also improve outreach and awareness-raising around the network.

Third, policy makers should not create a plethora of networks. A large number of networks will crowd each other out and will undermine the benefits that each network brings. It is much more important for policy makers to focus on providing high quality networks.

Fourth, public policy should support the use of online entrepreneurial networks. While their effectiveness is not known, they can be a low cost and easily-accessed structure. However, policy makers need to ensure that the network is dynamic so that members remain engaged. The impact will likely be greater if combined with face-to-face interactions.

Finally, it is crucial that policy makers design networking initiatives in such a way that the management and ownership of the network are transferred to the members. This is likely to build a higher level of trust and participation by members and potential members. 


\section{SUGGESTED FURTHER READING}

Drakopoulou Dodd, S. and J. Keles (2014), "Expanding the networks of disadvantaged entrepreneurs", prepared for the OECD LEED Programme.

Lockett, N., S. Jack and J. Larty (2013), "Motivations and challenges of network formation: Entrepreneur and intermediary perspectives", International Small Business Journal, vol. 31, No. 8, pp. 866-889.

OECD/The European Commission (2014), The Missing Entrepreneurs 2014: Policies for Inclusive Entrepreneurship in Europe, OECD Publishing. http://dx.doi.org/10.1787/9789264213593-en.

OECD/The European Commission (2013), The Missing Entrepreneurs: Policies for Inclusive Entrepreneurship in Europe, OECD Publishing. http://dx.doi.org/10.1787/9789264188167-en.

\section{BIBLIOGRAPHY}

Anderson, A.R. and Miller, C. (2002), "'Class Matters': Human and Social Capital in the Entrepreneurial Process", Journal of SocioEconomics, vol. 32, No. 1, pp. 17-36.

Beckinsale, M., M. Ram and N. Theodorakopoulos (2011), "ICT adoption and e-business development: Understanding ICT adoption amongst ethnic minority businesses", International Small Business Journal, vol. 29, No. 3, pp. 193-219.

Birley, S. (1985), "The role of networks in the entrepreneurial process", Journal of Business Venturing, vol. 1, No. 1, pp. $107-117$.

Birley, S., S. Cromie and A. Myers (1991), "Entrepreneurial networks: Their emergence in Ireland and overseas”, International Small Business Journal, vol. 9, No. 4, pp. 56-74.

Camagni, R. (1991), Innovation networks: spatial perspectives, London: Belhaven Press.

Carter, S., S. Anderson and E. Shaw (2001), “Women's business ownership: a review of the academic, popular and internet literature", RR002/01 report to the Small Business Service.

Drakopoulou Dodd, S. (2012), "Network approaches and embeddedness", in Mole, K. and M. Ram (eds.), Perspectives on Entrepreneurship: A Course Text, London: Palgrave Macmillan.

Drakopoulou Dodd, S., S. Jack and A. Anderson (2014), "The Role Of Networking In The Growth Processes Of Family Firms: An International Study", in A. Fayolle (eds.), Family Entrepreneurship, forthcoming.

European Commission - OECD (2012), "Policy Brief on Youth Entrepreneurship", Publications Office of the European Union, Luxembourg.

Ernst and Young (2013), "It's who you know: women entrepreneurs and the impact of networks", available at: http://www.ey.com/ Publication/vwLUAssets/EY_Its_who_you_know_Women_entrepreneurs_and_the_impact_of_networks/\$File/EY-Its-who-you-knowWomen-entrepreneurs.pdf.

Flandreau, M. (ed.) (2003), Money Doctors: History, Theory, Policy. The experience of international financial advising, 1850-2000, London: Routledge.

Glover, S., C. Gott, A. Loizillon, J. Portes, R. Price, S. Spencer, V. Srinivasan, and C.Willis (2000), "Migration: an economic and social analysis", London: RDS., RDS Occasional Paper No 67.

Granovetter, M. (1973), “The strength of weak ties”, American Journal of Sociology, Vol. 78, No. 6, pp. 1360-80.

Greco, G. and L. Floridi (2004), "The tragedy of the digital commons", Ethics and Information Technology, vol. 6, No. 2, pp. 73-81.

Greve, A. and J. Salaff (2003), “Social networks and entrepreneurship”, Entrepreneurship: Theory \& Practice, vol. 28, No. 1, pp. 1-23. 
Hampton, A., S. Cooper and P. Mcgowan (2009), "Female Entrepreneurial Networks and Networking Activity in Technology-based Ventures: An Exploratory Study”, International Small Business Journal, vol. 27, No. 2, pp. 193-214.

Hanifan, L. (1916), "The Rural School Community Centre”, Annals of the American Academy of Political and Social Science, Vol. 67, pp. $130-138$.

Hanna, V. and K. Walsh (2002), “Small firm networks: a successful approach to innovation?”, R\&D Management, vol. 32, No. 3, pp. 201-207.

Hite, J. M. (2005), "Evolutionary processes and paths of relationally embedded network ties in emerging entrepreneurial firms", Entrepreneurship Theory and Practice, vol. 29, No. 1, pp. 113-144.

Hoang, H. and B. Antoncic (2003), “Network-based research in entrepreneurship: A critical review”, Journal of Business Venturing, vol. 18, pp. 165-187.

Hongladarom, S. (2004), "Making information transparent as a means to close the global digital divide", Minds and Machines, vol. 14, No. 1, pp. 85-99.

Jack, S. (2005), "The role, use and activation of strong and weak ties: A qualitative analysis", Journal of Management Studies, Vol. 42, No. 6, pp. 1233-1259.

Jack, S., S. Dodd and A. Anderson (2008), “Change and the development of entrepreneurial networks over time: a processual perspective”, Entrepreneurship and Regional Development, vol. 20, No. 2, pp. 125-159.

Johannisson, B. (1996), "The dynamics of entrepreneurial networks”, in P. Reynolds, S. Birley, J. Butler, W. Bygrave, P. Davidsson, W. Gartner and P. McDougall (eds.), Frontiers of Entrepreneurship Research, Babson College: Wellesley MA.

Johannisson, B. and M. Mønsted (1997), “Contextualizing Entrepreneurial Networking”, International Journal of Management and Organization, vol. 27, No. 3, pp. 109 - 137.

Keeley, B. (2007), “OECD Insights: Human Capital - How what you know shapes your life”, Paris: OECD Publishing. DOI:10.1787/9789264029095-en

Kellard, K., K. Legge and K. Ashworth (2002), "Self-employment as a route off benefit", Research Report No. 177, Department of Work and Pensions, CDS, London.

Kim, P. and H. Aldrich (2005), "Social Capital and Entrepreneurship”, Foundations and Trends in Entrepreneurship, vol. 1, No. 2, pp. 64.

Larsen, J. and J. Urry (2008), "Networking in Mobile Societies", Mobility and Place: Enacting Northern European Peripheries, pp. 89-101.

Larson, A. and J. Starr (1993), "A network model of organization formation” Entrepreneurship: Theory and Practice, vol. 17, No. 2, pp. 5-15.

Lechner, C. and M. Dowling (2003), "Firm networks: External relationships as sources for the growth and competitiveness of entrepreneurial firms", Entrepreneurship and Regional Development, vol. 15, No. 1, p. 1-26.

Light, I. and E. Bonacich (1988), Immigrant entrepreneurs: Koreans in Los Angeles, Berkeley and Los Angeles: University of California Press.

Martinez, M. and H. Aldrich (2011), "Networking strategies for entrepreneurs: balancing cohesion and diversity”, International Journal of Entrepreneurial Behaviour \& Research, vol. 17, No. 1, pp.7-38.

Metcalfe, H. (1998), Self-employment for the Unemployed, Research Report No. RR47, Department for Education and Employment, HMSO, London. 
Mole, K., M. Hart, S. Roper, and D. Saal (2009), "Broader or deeper?: Exploring the most effective intervention profile for public small business support”, Centre for Small and Medium Sized Enterprises, Warwick Business School.

Morawska,E. (2004), “Immigrant transnational entrepreneurs in New York: Three varieties and their correlates", International Journal of Entrepreneurial Behaviour \& Research, vol. 10, No. 5, pp.325-348.

Nelson, R. (1988), "Social network analysis as an intervention tool”, Group and Organization Studies, vol. 13, No. 1, pp. 39-58.

Norris, P. (2001), Digital divide: Civic engagement, information poverty, and the Internet worldwide, Cambridge University Press.

OECD/The European Commission (2014), The Missing Entrepreneurs 2014: Policies for Inclusive Entrepreneurship in Europe, OECD Publishing. http://dx.doi.org/10.1787/9789264213593-en.

OECD/The European Commission (2013), The Missing Entrepreneurs: Policies for Inclusive Entrepreneurship in Europe, OECD Publishing. http://dx.doi.org/10.1787/9789264188167-en.

Pages, E. and S. Garmise (2003), “The power of entrepreneurial networking”, Economic Development Journal, Summer 2003, pp. 20-30.

Portes, A. (1998), "Social capital: its origins and applications in modern sociology", Annual Review of Sociology, vol. 24, pp. 1-24.

Portes, A. and J. Sensenbrenner (1993), "Embeddedness and immigration: notes on the social determinants of economic action", American Journal of Sociology, vol. 98, No. 6, pp. 1320-1350.

De Propris, L. (2000), "Innovation And Inter-Firm Co-Operation: The Case Of The West Midlands", Economics of Innovation \& New Technology, vol. 9, No. 5.

Ram, M. (2001), "Family dynamics in a small consultancy firm: A case study”, Human Relations, vol. 54, No. 4, pp. 395-418.

Schör, H. (2006), “The profile of the successful entrepreneur: Results of the survey 'Factors of Business Success'”, Eurostat, available at: http://ec.europa.eu/eurostat/documents/3433488/5580936/KS-SF-08-015-EN.PDF/b2c4bcf6-dbe7-4379-9b6b522c99eb6c65?version=1.0

Schott T. and M. Cheraghi (2012), "Entrepreneurs' Networks: Size, Diversity and Composition Shaped by Cultures of Rationality and Trust", Proceedings of the 2012 International Conference on Advances in Social Networks Analysis and Mining (ASONAM 2012), pp. 220-226.

Storey, D. (1994), Understanding the Small Business Sector, Routledge, London.

Storper, M. (1995), "Regional technology coalitions an essential dimension of national technology policy" Research Policy, vol. 24, No. 6, pp. 895-911.

Vanhaverbeke, W. (2001), "Realizing new regional core competencies: Establishing a customer-oriented SME network", Entrepreneurship and Regional Development, vol. 13, pp. 97-116.

Venkataraman, S. (2004), "Regional transformation through technological entrepreneurship", Journal of Business Venturing, vol. 19, pp. 153-167.

Vickers, I., F. Lyon and D. North (2009), "Removing barriers to Enterprise through Targeted Support for Disadvantaged Groups", Paper presented at ISBE Conference, November 2009.

Waldinger, R., H. Aldrich, and R. Ward, with the collaboration of J. Blaschke [et al.], (1990) Ethnic Entrepreneurs: Immigrant Business in Industrial Societies, Newbury Park, CA: Sage Publications.

Wang, C. and L. Altinay (2012), "Social embeddedness, entrepreneurial orientation and firm growth in ethnic minority small businesses in the UK”, International Small Business Journal, vol. 30, No. 1, pp. 3-23. 


This Policy Brief explains what entrepreneurial networks are, and how disadvantaged or under-represented groups can join them. Online networks in particular offer the added advantage of removing physical distances. The document also shows that by linking target groups with the business community, and helping the networks set up and widen their scope, the policy can provide real support. This Policy Brief is available online in English, French and German.

This Policy Brief is part of a series of documents produced by the OECD and the European Commission on inclusive entrepreneurship. The series includes policy briefs on youth entrepreneurship, senior entrepreneurship, social entrepreneurship, evaluation of inclusive entrepreneurship programmes, access to business start-up finance for inclusive entrepreneurship and entrepreneurship by the disabled as a well as a report on 'The Missing Entrepreneurs'. All these documents are available in English, French and German. They are available at http://www.oecd.org/cfe/leed/inclusive-entrepreneurship.htm.

\section{HOW TO OBTAIN EU PUBLICATIONS}

\section{Free publications:}

- one copy:

via EU Bookshop (http://bookshop.europa.eu);

- more than one copy or posters/maps:

from the European Union's representations (http://ec.europa.eu/represent_en.htm); from the delegations in non-EU countries (http://eeas.europa.eu/delegations/index_en.htm); by contacting the Europe Direct service (http://europa.eu/europedirect/index_en.htm) or calling 0080067891011 (freephone number from anywhere in the EU) (*).

(*) The information given is free, as are most calls (though some operators, phone boxes or hotels may charge you).

Priced publications:

- via EU Bookshop (http://bookshop.europa.eu).

\section{HOW TO OBTAIN OECD PUBLICATIONS}

- The OECD library: http://www.oecd-ilibrary.org

- The OECD Bookshop online: http://www.oecdbookshop.org 
This Policy Brief was prepared by the LEED (Local Economic and Employment Development) Programme of the OECD (Organisation for Economic Co-operation and Development) with the financial support of the European Commission, DirectorateGeneral for Employment, Social Affairs and Inclusion. 